\title{
Amended Final Study Report
}

National Cancer Institute

\section{Source}

National Cancer Institute. Amended Final Study Report. NCI Thesaurus. Code C158362.

A study report that has been signed by the study director and has been changed by correction, addition, substitution or omission. 